\title{
STEAM class-based creative thinking ability instruments for elementary school
}

\author{
Ahmad Fadhlilah ${ }^{1 *}$ \\ Rochmiyati $^{2}$ \\ Lilik Sabdaningtyas ${ }^{3}$ \\ 1,2,3 University of Lampung, Bandar Lampung, Indonesia
}

\begin{abstract}
The aim of this study was to analyze the need for developing appropriate science, technology, engineering, arts and mathematics (STEAM) assessment instruments (vaild, practical and effective) to improve students' creative thinking skills. The instruments that have been used in education units have not been fully able to encourage students to think at a higher level in building conceptual understanding and solving their own problems. This study used qualitative descriptive study based on a literature review of the STEAM-based assessment instrument as an effort to improve students' creative thinking skills. The research subjects were educators and fourth grade students of SD Negeri 2 Tulusrejo, Pekalongan District, East Lampung. The research object was creative thinking ability, assessment instrument, and STEAM. The data collection instrument used an interview guide. Questionnaire. An assessment instrument needed to support the learning process in the education unit to improve students' creative thinking skills. The finding indicated that educators had not fully used assessment instruments that could improve students' creative thinking skills. Besides, educators needed a STEAM-based assessment instrument that was appropriate to the level of the learner. Thus, it can be concluded that STEAM-based instruments to improve students' creative thinking skills in elementary schools must be developed.
\end{abstract}

\section{KEYWORDS}

Assessment; instrument; creative thinking ability; STEAM

Received: 2 August 2021

Accepted: 14 August 2021

Published: 16 August 2021

\section{Introduction}

The $21^{\text {st }}$ century skills emerge from an assumption that nowadays individuals live in the full of a technology environment, where there is an abundance of information, a very high acceleration of technological progress and new patterns of communication and collaboration. Success in this digital world is very dependent on the skills that are important to have in the digital era, covering critical thinking skills, problem solving, communication and collaboration (Hadinugrahaningsih, Rahmawati, \& Ridwan, 2017)

Thematic learning in Elementary Schools (SD) with 21st century-based learning still needs to be evaluated. This is due to there are still limited evaluation tools or student assessment instruments, which it leads to many educators create assessments that are only limited to memorizing for students. Assessment can be defined as a process taken to obtain information in order to make decisions about students, curriculum, programs, and other educational instruments by an official institution or institution that organizes a particular activity. It was also stated by Linn \& Gronlund (as cited in Uno \& Koni 2014:1) that assessment is a general term that includes procedures used to obtain information about student learning (observations, average written tests) and the format for assessing learning progress.

Creative thinking is one of the stages of high level thinking and it is needed in everyone's lives, and humans are always faced with problems so that creativity is needed to solve these problems. Azumardi as quoted by Suryosubroto (2009) argues that the educational paradigm must be based on a learning system that teaches creatively. Creative thinking is related to the ability to interpret phenomena. Another opinion, Torrance (as cited in Fasko, 2001) states "...when creative learning occurs, such as improved motivation, alertness, curiosity, concentration, and achievement. Thus, creative teaching can enhance learning". One of the most important abilities for students to acquire and develop in a variety of learning environments is creative thinking, which complements the acquisition of knowledge and skills that will be required in professional life (Waite \& Bromfield, 2002). 
Creative thinking skills that can realize creativity are really very important and needed by the nation today in order to create a better life for people who are able to create new discoveries from the contribution of their creative thinking. Thinking skills such as creative thinking skills are very important in the world of education. Being creative can be learnt through the teaching and learning process because creativity is the product of developing cognitive skills (Slameto, 2003). Learning is an effort made to acquire competence or in the form of abilities, skills and attitudes needed to do a job.

The results of interviews on the use of the STEAM approach and the use of assessment instruments in learning, it indicates that teachers do not yet know what the STEAM approach is in learning, thus, it can be assumed that teachers have never applied the STEM approach. In addition, teachers reveal that they still use the existing assessment instruments in the teaching materials they use. The assessment instrument has not led to the expected learning activities that can help students find their own concepts that are being taught and practice creative thinking skills. Educators have never made their own assessment instruments to be used in learning. Therefore, it is necessary to develop an assessment instrument using the STEAM approach which is useful for training students' creative thinking skill.

Dealing with the issue, we were interested in conducting research on STEAM-based creative thinking assessment instruments for fourth grade students in elementary schools.

\section{Method}

Analysis of qualitative descriptive studies based on literature review of assessment instruments equipped with a STEAM approach as an effort to improve students' creative thinking skills. The population in this study was the high class of SD Negeri 2 Tulusrejo. The sample in this study was the fourth grade students of SD Negeri 2 Tulusrejo, totaling 20 students. Data collection techniques used are interviews, questionnaires, and documentation.

\section{Results and discussion}

Regarding to the data obtained from the results of the needs analysis with the educator of fourth grade at SD Negeri 2 Tulusrejo about the instruments used to support learning. Educators have not used instruments that can improve students' creative thinking skills, especially STEAM-based instruments and they still used assessment instruments from the textbooks to teach.

Creative thinking skills need to be developed to support learning in the 21 st century. According to Susanto (2014) creative thinking can be interpreted as thinking that can connect or see things from a new perspective. While the characteristics of creative people according to Carin (Susanto, 2014) are Curiosity, resourceful, have the desire to find, choose difficult jobs, enjoy solving problems, have dedication to work, think flexibly, ask lots of questions, give answers who is better. , able to synthesize, able to see new implications, and have broad knowledge. (Martin, 2009) argues that being able to generate new ideas and ways to produce a product is being able to think creatively. The same opinion was expressed by (McGregor, 2007), namely creative thinking is thinking that leads to gaining new insights, approaches, perspectives, and ways when dealing with issue.

Creative thinking is a skill in carrying out a mindset based on a deep understanding of the concepts that an individual has previously mastered and that mindset will then influence the individual's mind to make changes. General problem for a teacher, it may be unusual for a student. Therefore, teachers must be able to develop learning methods or learning strategies that can develop the creative thinking power of their students (Noviani \& Wangid, 2018).

According to Holland (Mann, 2005) Aspects of creative thinking skills are fluency, flexibility, originality, elaboration, and sensitivity. Meanwhile, according to Torrance and Guiford (Munandar, 2009), creative thinking skills include abilities such as fluency, flexibility, originality, and elaboration. Creative thinking skills are also suitable for collaboration with 21 st century learning, namely STEAM learning.

The need to boost students' interest and skills in the subjects of Science, Technology, Engineering, and Mathematics (STEM) prompted the development of STEAM learning (Quigley, Herro, \& Jamil, 2017). STEAM blends "arts" with STEM study to increase student engagement, creativity, innovation, problem-solving abilities, and other cognitive benefits (Liao, 2016) and to improve employment abilities (such as teamwork, communication, and adaptability) that are important for professional and financial advancement (Colucci-Gray et al. , 2017).

STEAM is a learning approach that provides students the opportunity to expand their knowledge in science and humanities and at the same time develop the skills needed to thrive in the 21st century - such as communication skills, critical thinking skills, leadership, teamwork, creativity, resilience. , and other skills. STEAM was initiated by the Rhode Island School of Design which adds "arts" to the STEM framework. According to the Rhode Island School of Design, the goal is to foster thriving innovation by combining the mind of a scientist or technologist with that of an artist or designer. The addition of "arts" to the STEM framework is important as a practice, such as modeling, developing explanations, and eliciting criticism, and evaluation (arguments), which have so far been emphasized in the context of mathematics and science education. 
Art (arts), in this case, it is not just coloring or doodling on paper with crayons or paints, but showing the nonanalytical and creative side of a person's brain. The side of the brain that allows one to solve problems creatively, it enables individual to "think outside the box." Everything from signature art, music, dance, to "new" art, such as 3D printing falls into the art category (Perignat \& Katz-Buonincontro, 2018).

Various studies have shown that artistic activities, those have contributed to support and foster creativity, an important skill for innovation. STEM alone doesn't seem enough, but it must be combined with "arts" to become STEAM. The combination of STEM learning combined with the arts (STEAM) can provide opportunities to drive innovations that are important for the new world economy. Art enriches interdisciplinary learning and engages students in ways traditional pedagogy does not. Excluding A from STEAM means excluding some students. Art can be seen as a way in which students can reflect on, create, express, and represent ideas; as an alternative to reading, writing, speaking, and listening.

Creative thinking is often associated with critical thinking and problem solving. This is in accordance with the opinion of Tan (2009) who argues that "critical thinking skills are the same as the term of creative thinking”. Critical thinking emphasizes problem solving that produces the final result in the form of a strong argument on multiperspective information. A unique, strong and new argument implies that it has a creative content. The results of creative thinking serve to add the rich in knowledge.

Coon \& Mitterer (2014) argue that creative thinking or creativity is a problem-solving activity carried out through an unconscious experiential process which includes fluency in generating a number of ideas, flexibility, using time to produce various types of solutions, and novelty of ideas or solutions produced. New and fresh solutions and ideas require several stages. Fautley \& Savage (2007) and Coon \& Mitterer (2014) state that it consists of five stages including the following: 1) preparation stage, 2) concentration stage, 3) incubation stage, 4) illumination stage, and 5) verification stage.

\section{Conclusion}

Teachers has an important role in achieving educational goals. One of the educational goals that in the 21st century emphasizes students to have the ability to think creatively. STEAM is a learning approach that encourages students to have the opportunity for expanding their knowledge in the sciences and humanities and develop the skills needed in the 21st century. A creative thinking assessment instruments based on STEAM, educators can improve students' creative thinking skills. Several people argue that creative judgments are difficult to measure so that assessments are subjective. In this regard, a creative thinking assessment instrument is needed that aims to minimize the subjectivity of the assessment. Educators must develop creative thinking assessments not only on creative types of opinion, but other creative types such as creative processes and student products.

\section{References}

Colucci-Gray, L., Trowsdale, J., Cooke, C. F., Davies, R., Burnard, P., \& Gray, D. S. (2017). Reviewing the potential and challenges of developing STEAM education through creative pedagogies for 21st learning: How can school curricula be broadened towards a more responsive, dynamic, and inclusive form of education? British Educational Research Association.

Coon, D. \& Mitterer, J.O. (2014). Psychology: A journey. Fifth Edition. California: Wadsworth, Cengage Learning.

Fasko Daniel. (2001). Education and creativity. Creativity Research Journal. 13 (3 - 4), 317- 327.

Fautley, M. \& Savage, J. (2007). Creativity in secondary education. Southernhay East Exeter: Learning Matters Ltd.

Hadinugrahaningsih, T., Rahmawati, Y., \& Ridwan, A. (2017). Developing 21st century skills in chemistry classrooms: Opportunities and challenges of STEAM integration. AIP Conference Proceedings, 1868(1), 30008.

Liao, C. (2016). From interdisciplinary to transdisciplinary: An arts-integrated approach to STEAM education. Art Education, 69(6), 44-49.

Lister, Martin. (2009). New media: A critical introduction. London \& New York: Routledge.

Mann, J. J., (2005). The medical management of depressi. The New England Journal of Medicine. 17(353) 1819 - 1834.

McGregor, Debra. (2007). Developing thinking; Developing learning. Maidenhead: Open University Press

Munandar, Utami. (2009). Pengembangan kreativitas anak berbakat. Jakarta: Rineka cipta.

Noviani. Sumandita, M Wangid., (2008). Developing inquiry-based lectora multimedia in order to increase the logical ability and the creative thinking. Prima Educasia Journal. 6(1). 89-101.

Perignat, E. and Katz-Buonincontro, J. (2018). STEAM in practice and research: An integrative literature review. Thinking Skills and Creativity 31. 31-43.

Quigley, C. F., Herro, D., \& Jamil, F. M. (2017). Developing a conceptual model of STEAM teaching practices. School Science and Mathematics, 117(1-2), 1-12.

Slameto. (2003). Belajar dan Faktor-faktor yang mempengaruhinya. Jakarta: Rineka Cipta.

Susanto. Ahmad. (2014). Teori belajar dan pembelajaran di sekolah dasar. Jakarta: Kencana Prenada Media Group.

Suryosubroto. (2009). Proses belajar mengajar di sekolah. Jakarta: Rineka Cipta.

Tan, O. S. (2009). Problem-based learning and Creativity. Singapore: Cengage Learning Asia Pte Ltd.

Uno, Hamzah B., \& Satria Koni. (2014). Assessment pembelajaran. Jakarta: Bumi Aksara.

Waite S. \& Bromfield C. (2002). Promoting creative thinking through the use of ICT.Graduate School of Arts and Education and Rolle School of Education. University of Plymouth. Journal of Computer Assisted Learning. 18, 367- 378s. 